\title{
The semantics of metaphor and parable: Looking for meaning in the Gospels
}

\section{Introduction}

Human communication relies largely on metaphors. This applies to literature, to politics, to everyday interaction, to religion and to ethics. Indeed we live by metaphors, as the title of the well-known book by Lakoff and Johnson (1980) suggests. Yet despite their vital importance the meaning of metaphors is often far from clear - even to those who use them. The problem is compounded in cross-cultural communication, because while the letter of the metaphor can often be translated, the translated version may be baffling or deceptive.

In some areas of life - e.g. in ethics and religion - there are certain key metaphors whose meaning has been debated for centuries and no doubt will continue to be debated into the third millennium; and yet there is no widely accepted methodology with the aid of which such debates can be resolved and possible meanings clearly formulated.

In this paper I will try to show how the "Natural Semantic Metalanguage", based on 60 or so universal human concepts, can provide such a methodology. I will start with four basic assumptions.

My first assumption is that semantics is, so to speak, "for people"; its ultimate goal is to explain what things mean - and "explain" means "explain to people". Technical "semantic representations" constructed by linguists for the benefit of other linguists do no doubt have their place, too; but the ultimate test and the ultimate challenge is to be able to explain what something means - explain in such a way that people can understand what the explanation means. If the explanation itself is unintelligible then it doesn't fulfil its purpose.

My second assumption comes from Leibniz, and it is that not everything can be explained, and that the value of our explanations depends crucially on 
how self-explanatory our basic concepts are - our primitives, that is to say, those concepts that we are not going to try to explain. Our analysis can have an explanatory value only if it manages to "define" or explain complex and obscure meanings in terms of simple and self-explanatory ones. For example, there is no point in trying to explain - as many scholars do - the meaning of IF in terms of "implication", or the meaning of BEFORE in terms of words like "anterior", or the meaning of AFTER in terms of words like "posterior". If you don't know what IF, BEFORE and AFTER mean, then you won't know what "implication", "anterior", and "posterior" mean either.

My third assumption is that if one wants to explain meanings across languages and cultures one has to rely on shared, that is, universal concepts, and not on concepts which are culture-specific. Universal human concepts constitute the bedrock of human understanding, and to explain meanings across languages and cultures we need to rely on that bedrock. Empirical cross-linguistic investigations conducted over the last few decades, by a number of researchers, have led to the emergence of some 60 universal human concepts, which are given in the table below. In my explanations of the meaning of metaphors I will try to rely exclusively on these 60 or so concepts.

The set of universal human concepts (cf. Wierzbicka 1996. Goddard 1998)

[Substantives:]

[Determiners:]

[Quantifiers:]

[Evaluators: ]

]Descriptors:]

[Mental predicates:]

[Speech:]
I, YOU SOMEONE, PEOPLE/PERSON SOMETHING/THING, BODY THIS, THE SAME, OTHER ONE, TWO, SOME, ALL, MANY/MUCH GOOD, BAD

BIG, SMALL

THINK, KNOW, WANT, FEEL, SEE, HEAR SAY, WORD, TRUE

[Actions, events and movement:] DO, HAPPEN, MOVE

[Existence and possession:]

THERE IS, HAVE

[Life and death:]

[Time:]

LIVE, DIE

WHEN/TIME, NOW, BEFORE, AFTER, A LONG TIME, A SHORT TIME, FOR SOME TIME

[Space:]

WHERE/PLACE, HERE, ABOVE, BELOW,

[,Logical” concepts:]

FAR, NEAR, SIDE, INSIDE NOT, MAYBE,

[Intensifier, Augmentor:]

[Taxonomy, partonomy:] CAN, BECAUSE, IF VERY, MORE

KIND OF, PART OF

[Similarity:]

\section{LIKE}


My fourth assumption is that the meaning of metaphors, too, needs to be explained, and that it can be explained in non-metaphorical language, using the same simple and universal concepts in terms of which all other meanings can be explained. In particular, in ethical discourse such explanations are, I think, very important. A great deal can depend in human life, and in the life of society, on the understanding of metaphors like, for example, "an eye for an eye and a tooth for a tooth", or "turn the other cheek", whose meaning is hotly disputed.

In this paper I will focus on three extended metaphors, all from the "Sermon on the Mount": the metaphor of the left hand, the metaphor of a speck in one's brother's eye and the metaphor of building on the rock.

\section{Do not let your left hand know ... (Matt. 6:3)}

But when you do a charitable deed, do not let your left hand know what your right hand is doing.

The sentence about the left hand not knowing what the right hand is doing has puzzled many commentators. Betz (1995:358) has observed: "The proverb 'Let your left hand not know what your right hand is doing' is as famous as its meaning is disputed." By calling this saying a "proverb" Betz seems to be inviting the inference that it is not one of Jesus' original and unique sayings, carrying a original and unique message. In fact, however, there are good reasons to think that this saying became a proverb later (cf. Luz 1989:357), and Betz himself notes (ibidem): "Surprisingly, there do not seem to be parallels to this proverb in biblical, contemporary Greco-Roman, or Jewish sources". Parallels in later Arabic and Mandean literature, noted by Betz, could well depend on Matthew (as Luz believes they do). It is quite probable, therefore, that Jesus' saying was original. (As Funk and Hoover 1993 note, its paradoxical character is certainly consistent with Jesus' style).

What could Jesus have meant by this saying? Betz (1995) compares it with the Latin proverb "Manus manum lavat" ('one hand washes the other') and comments: "It is worth mentioning that both the Latin saying and the one in 6:3 have a slightly immoral tinge in that they describe daily dealings of some dubious nature. If one hand does not know what the other is doing, can this be anything but a sign of disorganization or dishonesty?"

But the implication of "disorganization", which is now linked with this saying when used as a proverb in both German and English, was clearly not part of the original meaning; and the same applies to "dishonesty". The Latin proverb does indeed suggest illicit dealings beneficial for the parties involved but the context makes it clear that there was no implication of dishonesty in Jesus' injunction. 
In fact, the context of this saying suggests, at least prima facie, an interpretation along the lines suggested, by (among others) John P. Meier (1980:58): "Disciples must give alms in complete secrecy, which is expressed by the hyperbole of the ignorant left hand."

The trouble with this interpretation is, however, that it is hard to reconcile with the logic of the image: the left hand is a part of the same person who is doing a deed (with their right hand), so how can it stand for other people? From this point of view, the idea put forward centuries ago by Clement of Alexandria (Stromata 4.138.2) seems far more convincing: namely, that the two hands stand for aspects of the same person, their deeds and their self-image (in my terms, doing and thinking): "If thou doest alms, it is said, 'let no one know it; and if thou fastest, anoint thyself, that God alone may know, and not a single human being. Not even he himself who shows mercy ought to know that he does show mercy".

In modern times, this interpretation was passionately championed by Dietrich Bonhoeffer. Commenting on the apparent contradiction between Jesus' injunction that the good deeds of his disciples should be visible to other people (Matt. 5:16) and the injunction that they should also be "hidden", Bonhoeffer (1959(1937]: 142) commented: "There is a pointed contrast between chapters 5 and 6 . That which is visible must also be hidden. (...) We have to take heed that we do not take heed of our own righteousness." Bonhoeffer asks: "How is this paradox to be resolved?" And he replies: "The first question to ask is: From whom are we to hide the visibility of our discipleship? Certainly not from other people, for we are told to let them see our light. No. We are to hide it from ourselves." (ibid.) And this is, according to Bonhoeffer, what the metaphor of the left hand means: "All that the follower of Jesus has to do is to make sure that his obedience, following and love are entirely spontaneous and unpremeditated. If you do good, you must not let your left hand know what your right hand is doing, you must be quite unconscious of it. (...) If the left hand knows what the right hand is doing, if we become conscious of our hidden virtue, we are forging our own reward." (p. 143).

I believe that Bonhoeffer's interpretation is insightful and essentially right. Unfortunately, however, it was phrased in a way which alienated other commentators instead of convincing them. To some, it sounded as if Jesus was urging some new kind of hypocrisy and seif-deception: pretending to oneself that one doesn't know what one is doing while of course knowing it perfectly well. For example, Luz (1989:357) insists, with reference to Bonhoeffer, that the saying about the left hand not knowing what the right hand is doing "must not be pressed. It does not mean that 'even the person who practices the mercy may not know that he or she practices mercy'. The ideal conception of doing 'entirely spontaneous and unpremeditated good' [cf. Bonhoeffer 1959[1937]: 138] is alien 
to the text. The image only means: Nobody, not even the closest confidant, needs to know about your almsgiving".

Strecker (1988:100-101) comments as follows (also with reference to Bonhoeffer): „According to a wide-spread interpretation it means that proper doers of good deeds are not conscious of them. (...) Yet the Preacher on the Mount aims his demand of righteousness at the doings of people who are conscious of their own selves. What is required is not a renunciation of the knowledge of one's own actions; rather, the proverbial expression makes clear the required action, which - because it occurs in secret - is set against the externally focussed behavior of the hypocrites. The doing of good is supposed to remain hidden, not from the doer, but from the people, in order to escape public honor as the substitute for heavenly reward."

Betz (1995:358), too, rejects Bonhoeffer's interpretation when he writes: "The point in SM/Matt. 6:3 is not that almsgiving should be done in such a way that the donor is not aware of the act. Rather, the donor's knowledge of the gift should not be used to let others know of it, but to keep it secret".

As I mentioned earlier, however, the problem with Bonhoeffer's interpretation may lie more in its slightly unfortunate phrasing than in the basic idea. It would indeed be hard to accept that "the donor should not be aware of the act" (Betz), or that what is required is "a renunciation of the knowledge of one's own actions" (Strecker). I think, however, that Bonhoeffer's (and Clement of Alexandria's) main idea would not be so vulnerable to criticisms if it were rephrased as follows:

sometimes when a person is doing something good for other people this person thinks: „I am doing something good for other people”

(because of this, this person feels something good)

it will not be good if you think like this

when you are doing something good for other people

As I see it, the question is not what the doer of a good deed knows but what he or she thinks; and if they think: "I am doing something good for other people" men this does smack of self-congratulatory smugness and self-righteousness of the kind that Jesus denounced in his teaching (for example, in the parable of the Pharisee and the Taxcollector). Whether or not a component making the smug feeling explicit (,,because of this, this person feels something good") is justified is a question which I will leave open.

To insist that Jesus' saying about the ignorant left hand suggests nothing more than doing good deeds in secret is to deny that this saying adds anything to the message of verses 2 and 4. If, however, it is interpreted along the lines suggested here (that is to say, in accordance with Clement of Alexandria's, and Bonhoeffer's, approach) it adds a great deal. 
In addition to repudiating smug and self-congratulatory attitudes, verse 3 also throws important light on the meaning of "reward" in Jesus' speech, notably, on the question of whether it is meant literally, as for example, Limbeck (1995), Strecker (1988) or Betz (1995) believe, or metaphorically, as for example Jeremias ( 1971 ) insists.

I have quoted Strecker (1988:101) as saying that "the doing of good is supposed to remain hidden, not from the doer, but from the people, in order to escape public honor as the substitute for heavenly reward". This means that the doer of good deeds is conscious of his or her good deed and does expect a "heavenly reward". Betz (1995:360) puts this view even more bluntly when he says (commenting on Matt. 6:4) that "the reason for secrecy is to protect one's eschatological reward: 'and your Father who sees in the hidden will compensate you' (...) A good deed done in this way has been done according to God's will and as the Torah requires, but its reward is still outstanding".

But the desire to "protect one's eschatological reward" presupposes the thought "I am doing something good (for other people)" or "I have done something good (for other people)". I have tried to show, however, that such a thought would be inconsistent with the image of the ignorant left hand. If such a thought is absent then there can be no thought of "protecting one's eschatological reward" either.

The question of what the "doer of good deeds" is thinking is crucial from Jesus' point of view, as the parable of the Pharisee and the Tax-collector clearly illustrates. Strecker (1988:101) says that in 6:1-18 "Matthew wants to emphasize the necessity of doing good deeds with a view toward God and not in the view of people". Simone Weil (1951:151), on the other hand, has suggested that any thought about God (let alone about a "heavenly reward") would detract from the value of a charitable deed in God's eyes. On her interpretation, when one is doing a charitable deed, it is not the time to turn one's thoughts towards God. "There are times when thinking of God separates us from him. (...) He who gives bread to the famished sufferer for the love of God will not be thanked by Christ. He has already had his reward in this thought itself. Christ thanks those who do not know to whom they are giving food."

Simone Weil's interpretation suggests a focus on the person for whom the doer is doing the charitable deed rather than on God (let alone oneself or one's "heavenly reward"); that is to say, a thought which can be represented as follows:

something bad has happened to this person (people)

I want to do something good for this person (these people) because of this

Such an other-centred thought appears to be quite consistent with the attitude of the good Samaritan, who, when he saw the wounded man, "had compassion on him" (Luke 10:33). If, however, the good Samaritan had started to think 
while bandaging the man's wounds: "I am now doing something good for another person" (and to feel something good because of this) this would mean that the left hand did know what the right hand was doing, and the Samaritan would be having his reward there and then. On Simone Weil's interpretation, even the thought 'I'm now doing something good for God" could be seen as the left hand knowing what the right hand is doing.

Strecker (1988:102), who strongly emphasizes the motive of reward in Matt. 6:1-4, 5-8, and 16-18, feels compelled, as a result, to question the authenticity of these sayings. Having quoted Braun's ( 1969, 2:56) statement that "the naive expectation of reward was de facto overcome by the core of Jesus' message" he comments: "This compels the conclusion that the inferred pre-Matthean form of the three catechetical pieces presumably does not go back to Jesus" (p.102). But this conclusion is quite unnecessary if the references to "reward" in Jesus' sayings are interpreted as metaphorical and ironic, as Jeremias (1971) has urged they should be and as Jesus' teaching about the left hand not knowing what the right hand is doing clearly encourages us to do.

On the interpretation proposed here, Jesus' sayings using the word "reward" can be seen as entirely consistent with "the core of Jesus' message", in which "the naive expectation of reward was de facto overcome". In fact, the saying about the left hand not knowing what the right hand is doing epitomizes one of the central themes in Jesus' teaching: his condemnation of self-righteousness, of seeing oneself as a "good person" and a "doer of good things"; in his teaching, people are certainly expected to do "good things", but with a different mindset.

\section{Do Not Judge (Matthew 7:1-5: cf. Luke 6: 3-7)}

1. Judge not, that you be not judged.

2. For with what judgment you judge, you will be judged; and with the same measure you use, it will be measured back to you.

3. And why do you look at the speck in your brother's eye, but do not consider the plank in your own eye?

4. Or how can you say to your brother: 'Let me remove the speck from your eye'; and look, a plank is in your own eye?

5. Hypocrite! First remove the plank from your own eye, and then you will see clearly to remove the speck from your brother's eye.

Here again, the first question must be: did Jesus really say these things? And the prevailing view of the commentators is that he did. Indeed even the scholars of the Jesus Seminar, who are usually more sceptical than many others, were prepared to attribute to Jesus the "mote and beam" passage, in which "vivid, 
exaggerated, and humorous images are used (...) to call attention to the heavy irony of fault-finding" (Punk and Hoover 1993:154), although the first two verses of the passage in question (,Judge not," down to "it will be measured back to you”), were not regarded by them "as sufficiently distinctive to be attributed to Jesus".

There is no reason, however, to assume that only "distinctive" sayings (dissimilar to anything that anyone else had said in Palestine or elsewhere in the ancient world) can be plausibly attributed to Jesus. Furthermore, it is impossible to know whether a saying is "distinctive" before its meaning has been elucidated; otherwise, a superficial similarity in words and images can conceal the novelty and distinctiveness of the message. From a formal point of view, a short and readily remembered saying like "Judge not, that you be not judged" could easily have survived the oral period of transmission of Jesus' sayings and the fact that it was recorded by both Matthew and Luke lends further support to its authenticity. Above all, however, the idea behind the instruction "Do not judge..." plays such an important role in the Gospels as a whole, recurring in a variety of genres, that it can rightly be regarded as one of key themes of Jesus' teaching.

But to establish the role and significance of this theme in Jesus' teaching, we have to determine the meaning of the key injunction "Do not judge..." - a meaning which, as the history of its exegesis shows, is open to many different interpretations. As Betz (1995:487) notes,

The history of the interpretation of the passage reveals a great deal of uncertainty regarding the precise meaning. Some determine the content by looking at vss [verses] 12 , other by focussing on vss 35 . Tolstoy thought that the social demand of abolishing the entire system of public justice is stated in these words, while Welltonsen, arguing against Tolstoy, thinks of a moral injunction against private judging that was much in vogue among Jews and Christians, an ugly vice to be rooted out from human fellowship. Thus, determining the very content of the passage depends to a large extent on the presuppositions with which one approached it.

Betz (1995:493) himself casts his vote for an interpretation based on the idea of "prudence": "the rule implies that judging others is not such a bad thing, but to do it rightly one must keep the proper procedures in mind. The requirement is indispensable because on it rests justice and fairness. (...) it can be recommended as prudence.” Betz ( 1995:490) elaborates:

The kind of judgement one passes on others comes back to the person who started it. Gossipers become targets of gossip; critics must face being criticised, and so forth. The prudent person, so goes the advice, will break the vicious cycle by withholding such judgment because the same mechanism will work in the reverse direction as well. Restraint will motivate others to exercise equal restraint. 
The idea that "not judging others" should be justified by "prudence" is evidently based on a literal, or almost literal, interpretation of verse 2: "For with what judgment you judge, you will be judged; and with the same measure you use, it will be measured back to you." But is this really justified? Doesn't the threat of judgment refer symbolically to the Last Judgment and isn't it used here to emphasize the seriousness of the exhortation? The symbolic character of the language used in this passage was clearly recognized in St. Augustine's commentary on the Sermon on the Mount where he asks: "Can it be (...) that if we give expression to a judgment that is rash, God will also judge us rashly? Or if we measure with an unjust measure, that in God's case too, there is in store an unjust measure by which it shall be measured to us again?" St. Augustine's questions are of course rhetorical, and he replies to them: "No, not at all. God neither judges rashly nor does He requite with an unjust measure." Nonetheless, St. Augustine, too, suggested that "the very rashness with which you penalize another must rebound on you"; and Betz' idea of "prudence" is consistent with this suggestion.

It is hard to see, however, how the idea of praiseworthy "prudence" could be reconciled with the vehemence of verse 5: "Hypocrite! first remove the plank from your own eye, and then you will see clearly to remove the speck from your brother's eye." The image of the plank and the speck and the sharp rebuke which follows them suggest that what Jesus is concerned about is not the "imprudence" of judging other people, but the presumption of condemning other people (who do bad things) as "bad people" and setting ourselves above them as their judges - as if we were not like them ourselves and never did "bad things".

The image of the plank and the speck (or beam and mote) is of course hyperbolic, and deliberately so. It is hard to see how such a paradoxical metaphor could be used to encourage moderation and restraint in anything. This is why I find comments like the following rather unconvincing (Betz 1995:490-492):

The context clearly implies that krinein [,pass judgment"] refers to the perpetual human obsession to criticize and correct the behavior of other people (...) It is true that human conduct inevitably involves taking the measure of each other (...) What is criticized (...) is the degeneration of this process. This happens when a person denigrates another by harsh and unfair criticism, with a lack of sympathy and understanding, if not a pathological delight ( $\mathrm{p} 490$ ). The person who is unable or unwilling to see his or her flaws lacks selfcriticism and is, for this reason, declared incompetent to criticize another, (p 492)

Comments of this kind do not do full justice to the ethical radicalism of Jesus' "absolute prohibition of judging" (Strecker 1988:143) - a radicalism which prohibits thinking of anyone "this person is a bad person" and of regarding anyone who "does bad things" as radically different from myself (,I am not someone 
like this"). This is why Betz is in my view much more on target when he links (in a footnote) the "judging" attitude with the characters of the Pharisee (Luke 18:9-14) in the parable of the Pharisee and the Tax-collector and of the older brother in the parable of the Prodigal Son (Luke 15:25-32). The powerful images of the Pharisee and the older brother are indeed most illuminating in the present context, because they involve the notion of dividing people into two categories: "good people" - for example, "myself", and "bad people", who are not "like me" (e.g. the tax-collector, or the prodigal son).

A division of this kind goes far beyond vices such as "the perpetual human obsession to criticize and correct the behavior of other people, in particular those with whom one is closely associated" (Betz 1995:490). In fact, the Pharisee in the parable was not closely associated with the tax-collector, and was not obsessed with criticizing or correcting either him personally or other tax-collectors. He did, however, regard tax-collectors as "bad people" and "not like me" - and so, according to the parable, he did not go to his house justified.

Above all, however, Jesus' attitude to "judging other people" and the meaning of the exhortation "do not judge" have been made clear in the story of the woman caught in adultery, reported in the Fourth Gospel (John 8:2-11). Since this story provides a vital commentary on the exhortation "do not judge" I will quote it here in extenso.

2. But early in the morning he came again into the temple, and all the people came to him; and he sat down and taught them.

3. Then the scribes and Pharisees brought to him a woman caught in adultery. And when they had set her in the midst,

4. They said to him, "Teacher, this woman was caught in adultery, in the very act.

5. "Now, Moses, in the law, commanded us that such should be stoned. But what do you say?"

6. This they said, testing him, that they might have something of which to accuse him. But Jesus stooped down and wrote on the ground with his finger, as though he did not hear.

7. So when they continued asking him, he raised himself up and said to them, "He who is without sin among you, let him throw a stone at her first."

8. And again he stooped down and wrote on the ground.

9. Then those who heard it, being convicted by their conscience, went out one by one, beginning with the oldest even to the last. And Jesus was left alone, and the woman standing in the midst.

10. When Jesus had raised himself up and saw no one but the woman, he said to her, "Woman, where are those accusers of yours? Has no one condemned you?"

11. She said, "No one, Lord." And Jesus said to her, "Neither do I condemn you; go and sin no more." 
The story of the adulteress, which is not found in any of the important early Greek manuscripts, is widely regarded as a later insertion in the Forth Gospel. Nonetheless, it is also widely accepted as a truly ancient story. As noted by Brown (1966:335), "Ambrose and Augustine wanted it read as part of the Gospel, and Jerome included it in the Vulgate". Why then, Brown asks, "did it not immediately become part of the accepted Gospels?" And he replies, "Riesenfeld [ 1952] has given the most plausible explanation for the delay in the acceptance of this story. The ease with which Jesus forgave the adulteress was hard to reconcile with the stern penitential discipline in vogue in the early Church. It was only when a more liberal penitential practice was firmly established that this story received wide acceptance."

The story, which in Brown's words portrays Jesus "as the serene judge” (p. 336), portrays also with great clarity the "holier than thou" attitude at which Jesus' exhortation in Matthew (7:1-5) is aimed. It also highlights the basic point that "God alone is good" (cf. Matt. 19:17), and therefore God alone can judge people. People can judge deeds, but they cannot "judge" other people (in the sense of condemning them as "bad people"), because those who set themselves up as judges do bad things themselves. Nobody, therefore, is in a position to say about another person: "this person is a bad person, this person is not someone like me". This is, essentially, what Paul says about "judging other people" in his letter to the Romans (2:1): "Therefore you are inexcusable, O man, whoever you are who judge, for in whatever you judge another you condemn yourself; for you who judge do the same things".

The story of the adulteress is so unforgettable and so quintessentially Jesus- like that even the Fellows of the Jesus Seminar, who decided that the words attributed to Jesus in the story "did not originate in their present form with Jesus", nevertheless "assigned the words and story to a special category of things they wish Jesus had said and done" (Funk and Hoover 1993:426).

There is a certain irony in this assessment and a perhaps unintended tribute to Jesus. Both the story and the words bear an unmistakable imprint of Jesus' personality . Obliquely, the Fellows are saying in their commentary: "if this is not Jesus speaking then let's imagine another Jesus, even more Jesus-like than Jesus himself, and let's attribute these words and this story to him". The simplest possibility, however, is to accept that this is Jesus speaking. One can also ask: where else would the Fellows have found the "higher ideal" in the name of which they wish "Jesus had said and done" such things?

This, then, is my proposed explication of the "Do not judge..." passage Matthew 7: $1-5)$ :

Do not judge...

(a) people often think about another person:

(b) "this person is someone bad 
(c)

this person is not someone like me"

(d) I say to you:

(e) it will be bad if you think like this about another person

(f) if you think that someone did something bad

it will be good if you think at the same time: "this person is someone like me I do bad things like other people do bad things" it will be good if you think something else at the same time:

"I don't know everything about this person

God knows everything about this person

like God knows everything about me"

I suggest that essentially the same explication can be assigned both to the abstract injunction "Do not judge" and to the image of removing the speck (or the mote) from one's brother's eye. The contrast in size between the plank (or the beam) in my own eye and the speck (or the mote) in my brother's eye is not meant to convey that my sins are necessarily greater than those of other people; rather, it is meant to convey that my blindness must be truly colossal if I don't realize that I, too, do bad things. The bad things that I do should be especially clear to me because I know my thoughts, whereas in the case of other people I don't know what really happens in their hearts.

The explication proposed here for both the abstract injunction and the metaphor does not say that it is bad to say about someone else that they have done something bad. Jesus' injunction "do not judge" should not be confused with the idea reflected in the late twentieth century English word judgmental. To quote two recent examples:

1. A criticism sometimes made of moral welfare workers is that they are judgmental in their approach to clients. (1965) (OED 1992)

2. "and you should treat people fairly and not judge them, and, um, moralistically...Diversity. I don't think we should be judgmental of other people. (From a set of interviews conducted in the US in the 1990s. Porpora 2001.)

Roughly speaking, the word judgmental suggests that one has (and tends to express) strongly negative views about other people's personal lives, which should not really concern us. It is related to the modern ideals of tolerance, broadmindedness, and respect for other people's opinions, values, and private lives. A person who is seen as "judgmental" is someone who (from the speaker's point of view) fails to understand, or to accept, that what he or she sees as "bad" may not, be seen as "bad" by everybody else. There is an assumption here that one must not impose one's own standards on other people; in their private lives (if not more generally), other people have the right to adopt their own standards, and 
their own values. Usually a line is drawn at actions negatively affecting other people; but as long as someone's actions do not affect other people it is thought that one has no right to condemn those actions as "bad". This modern notion that it is bad to be "judgmental" can be represented along the following lines:

being judgmental

(a) some people want to say about other people:

(b) "these people do bad things

(c) it is bad if someone lives like this"

(d) it is not good if someone says this about other people

(e) it is not good if someone thinks like this about other people

The Pharisees who brought to Jesus the woman caught in adultery saw this person as "a bad person, who did something bad". A modem reader of the Gospels might think that they were being "judgmental" (in the modern sense of the word), but this was not Jesus' point. He was not implying that different people can have different moral standards and in particular, he was not relativizing the moral status of adultery. At the same time, however, he was pointing out that since all people do bad things no one is in a position to say about another person: "this person is a bad person, this person is not someone like me".

The explication proposed here allows us better to see why exactly Tolstoy was wrong in assuming that Jesus had condemned all human law and judicial systems. Tolstoy claimed that "the human courts were not only contrary to his [Jesus'] commandment but in direct opposition to the whole doctrine of Christ and that therefore he must have forbidden them (...) Christ says: 'Make no distinction between the just and the unjust'. Courts of law do nothing else. Christ says: 'Forgive all. (...) 'Love your enemies.' 'Do good to them that hate you.' Courts of law do not forgive, but they punish (...). So that the true sense of the doctrine is that Christ forbids all courts of law" (1958 [1884]:25).

But consider the two key components of the explication proposed here: "this person is a bad person, this person is not someone like me". Do the judges in the human courts have to think about the accused in such terms? Clearly not. The judges have to focus on the question of the accused person's deeds, and not on the question whether the accused is "a bad person", and a "person not like me". So the injunction: "Do not judge (people) does NOT mean that Jesus condemned all human law and justice. But to see this clearly, we need to explicate the real meaning of the injunction, rather than look at the words as such. The point is not that Jesus' words were meant to apply to private life and not to public life, as many commentators have alleged (cf. Bauman 1985:19), but that deeds should be distinguished from people.

Tolstoy refers in this context to the story of the woman caught in adultery, and he states: „In the case of the adulteress, he [Jesus] positively rejects human 
justice and proves that, on account of each man's own sinful nature, he has no right to judge another" [p.26]. Tolstoy treats here the words "Do not judge ..." as if they were unambiguous and self-explanatory. In fact, however, they are not self-explanatory and to really understand them we need to go beyond the surface of the text and explicate its deeper meaning, in the context of the Gospel as a whole; and this is what I have tried to do.

\section{Building on the Rock (Matt. 7:24-29: Luke 6:46-51)}

24. Therefore whoever hears these sayings of mine and does them, I will liken him to a wise man who built his house on the rock:

25. and the rain descended, the floods came and the winds blew and beat on that house; and it did not fall, for it was founded on the rock.

26. Now everyone who hears these sayings of mine, and does not do them, will be like a foolish man who built his house on the sand:

27. and the rain descended, the floods came, and the winds blew, and beat on that house; and it fell. And great was its fall.

28. And so it was, when Jesus had ended these sayings, that the people were astonished at his teaching,

29. for he taught them as one having authority, and not as the scribes.

The image of two houses and two foundations has parallels in other traditions, and on this basis some commentators have questioned the authenticity of Matthew's "parable of the Two Builders" and of its close counterpart in the concluding part of Luke's Sermon on the Plain. For example, Funk and Hoover (1993:158-9) have printed both the Matthean and the Lucan version of this parable in black (as "non-authentic") and have commented on the Matthean version of it as follows: "The image of the two foundations belongs to common Israelite, Judean and Rabbinic lore. Several rabbis of the late first and early second centuries are credited with creating similar parables to stress the need of putting teaching into practice" (p. 158-9); and on the Lucan version: "The analogy of two kinds of foundations for houses was well known in the ancient Near East. If Jesus made use of such images, he was drawing on the general fund of wisdom sayings. For this reason, and because the complex provides no additional information about who Jesus was, the Fellows designated the passage black." (p. 299).

The Fellows' conclusion that the passage is commonplace and doesn't tell us anything about Jesus contrasts sharply with the reaction of Jesus' listeners as depicted by Matthew: "the people were astonished at his [Jesus'] teaching, for he taught them as one having authority, and not as the scribes." Of course, it can be said that people's alleged astonishment (not mentioned by Luke) was invented 
by Matthew, as a narrative device. It can also be said that people were astonished at Jesus' magisterial manner rather than at the content of his teaching. But while Jesus' manner was indeed very different from that of other Jewish teachers (as generally agreed), in the parable of the Two Builders the message was very different, too. Other Jewish teachers spoke, and wrote, as commentators on Torah and as transmitters and interpreters of an ancient tradition. Jesus, on the other hand, spoke of his own teaching as the rock on which people can build their lives. As noted by Jeremias (1971:254), "In contemporary Judaism, it was said, 'The person who hears the words of the Torah and does good works builds on firm ground'; here we have, 'The person who hears my words' (Matt. 7.24- -27).” In John 7:46, the men sent to Jesus by the Pharisees are reported as saying: "No man ever spoke like this man!" Thus, while throughout the Sermon on the Mount, the how may have been more astonishing to the crowds than the what, in the final passage the difference between the how and the what virtually evaporates, since here the Matthean Jesus claims that his own teaching can provide people with an unshakeable foundation for their lives.

According to Jesus' own explanation (in verse 24), building a house on the rock means not just hearing his words but "doing" them. Commentators agree that in fact this is what the final passage of the Sermon on the Mount is all about: it is about "hearing" and "doing", that is about "doing" what one has "heard". But what exactly does it mean? Since the phrase "these sayings of mine" refers to a long series of sayings rather than to any single injunction, and since these sayings do not refer to actions (,do this" or "don't do that") but rather to attitudes (e.g. "love your enemies" or "do not worry about your life"), the intended meaning may be less obvious than it seems at first sight. I submit that what "doing Jesus' words" means in this context is living according to the Sermon on the Mount, "living like this". As John P. Meier (1980:75) puts it, commenting on this passage, "the wise disciple forms his whole existence according to these words; he does them", and A. M. Hunter (1953) refers to "The Sermon on the Mount" as Design tor Life. "Doing” Jesus' words, then, means living in a certain way. In the Sermon : $\mathrm{n}$ the Mount, Jesus the builder (for that's what tecton meant, rather than specifically carpenter') tells people how to build the house of their life.

I do not agree, therefore, with interpretations according to which "building - house on the rock" means essentially "obedience". For example:

Is there any word in which hearing and doing are summed up? There is such a word, and that word is obedience. Jesus demands our implicit obedience. To learn to obey is the most important thing in life. (...) It is Jesus' claim that obedience to him is the only sure foundation for life; and it is his promise that the life which is founded on obedience to him is safe, no matter what storms may come. (Barclay 1993:292). 
Similarly, Jeremias ( 1966:153) comments on the parable of Two Builders as follows:

The Scripture said that only the house built on the sure foundation-stone laid in Zion would abide the onset of the flood (Isa. 28.15) (...). Jesus' contemporaries taught that the man who knows and obeys the Torah cannot be moved. Jesus takes them back to the Scriptures, but he gives a new answer, drawn from his own profound consciousness of authority: 'Everyone who hears these words of mine and does them ...' Merely knowing about his words leads to perdition; everything depends on obedience.

This is a Bultmannian (1958[1926]) interpretation of Jesus' teaching, with "obedience" being the central concept. Barclay even goes so far as to extol those ready "automatically and unquestioningly to obey orders", whereas Jeremias stresses that "The obedience must be complete.' In my view, however, this is not what the parable of Two Builders is about. The basic message of the Sermon on the Mount is that people can live in the Kingdom of God; it is, in effect, a pressing invitation for everyone to do so, and a set of guidelines on how to live if one wants to accept the invitation. These guidelines do not constitute commands: "Do this!" or "Don't do that!", so they cannot be obeyed or disobeyed. Counsels such as "Love your enemies" or "don't judge other people" cannot be a matter of "obedience". It is not a question of "doing something" but of "living in a certain way"; and this way of living counselled by Jesus refers to a person's thoughts, intentions, and feelings as much as - or more than - as to actions. Accordingly, Jesus' summing up in verse 24 (Matt. 7:24) can be represented in universal human concepts as follows:

(a) I say all these things because I want people to know that they can live with God

(b) if you hear my words you can think: ,if I live like this (can live with God)

(c) it will be good for you if you think this

(d) it will be good for you if you live like this because of this

(e) it will be very bad for you if you don't live like this

The Sermon on the Mount confronts every individual hearer with the thought: "if I live like this I can live with God", and, consequently, with the question: "do I want to live like this because of this?" Jesus assures every individual addressee that it will be good for them to live like this (that is, to try to follow the model of life outlined in the Sermon on the Mount), and warns them that it will be very bad for them if they don't. The parable of the Two Builders amplifies this assurance and this warning with symbolic images.

The exact meaning of these images is disputed. Some commentators think that the rain, flood and wind refer to personal catastrophes which may befall 
a person in their earthly life (cf. e.g Limbeck 1995:129-30); others think that they refer, rather, to God's judgment and to the absolute value of a person's life as it will be revealed to him or her at the time of that judgment. For example, Jeremias (1966:153) comments as follows: "As the torrential autumn rains, accompanied by storms, test the foundation of the houses, so the deluge will set in overnight and put your lives to the test. The Sermon on the Mount ends with the last judgment! Who will survive it? The 'wise man', i.e. the man who has recognised the eschatological situation". Jeremias implies that flood does constitute, in effect, a global and cosmic image, when he says, with reference to Isaiah 28:15, that according to the Scripture "only the house built on the sure foundation-stone laid in Zion would abide the onset of the flood". (See also Strecker 1988:171-172.)

The two lines of interpretation are not necessarily incompatible. To my mind images of storms and floods seem to fit life's misfortunes and disasters rather better than they do the last judgment. Apocalyptic images tend to be global and cosmic, whereas rains, winds, storms, and torrents point, rather, to more local and personal disasters. In any case, however, an existential interpretation makes I think a great deal of sense. For regardless of God's, and one's own, final judgment about one's life as a whole, from the point of view of a person in the middle of his or her life (,,in the midst of earthly life", in the words of one of Luther's well-known hymns) the question of their existential security must loom large - often even larger than their eschatological security. Since any thinking person knows that a misfortune, and indeed disaster, can strike at any moment, they need to know whether they have some rock on which they could stand in such an event - something that would not be washed away. And the Matthean (and Lucan) Jesus says that his words can provide such a rock. Tentatively, I would represent this as follows: if you live like this, you can always live with God you know that some very bad things can happen to you at some time if you don't live with God, you can think then: "I can't live now" if you live with God you will not think like this you will know that you can always live if you live with God

Component (f) links "living like this" (that is, living in accordance with the teaching of the Sermon on the Mount) with "living with God" (not only after one's death but before as well - "always"). Component (g) refers to possible misfortunes and disasters; ( $h$ ) refers to existential despair which could befall a person at such a time, and both (i) and (j) show how "living with God" would protect a person from such a despair and give them a sense of unassailable security and hope. This is contrasted with the sense of existential insecurity and defencelessness of a person who is not living with God (component $h$ ): "if you don't live with God, you can think then: T can't live now"'. 
Limbeck et al. ( 1987:130) stress that the Sermon on the Mount has a message not only for those who are concerned about their future after death but also for everyone else. "It is significant for all those who don't want to live in vain, who want to build their house not on sand but on rock. (...) The individual decides here (...) whether his or her life in this world will become 'a bit of eternity' or whether their earthly past will at one time collapse and disappear as worthless and groundless". This interpretation is somewhat different from the one suggested here because it doesn't refer to existential despair in the face of misfortunes and disasters. But it is not inconsistent with it and could be incorporated into the proposed explication.

It should be pointed out that the explication proposed here has both an existential and an eschatological dimension (that is, it refers both to life before death and to life after death). In particular, component (j) refers to both moral courage and strength that a person can find in the face of a disaster and to faith that even if one died one can live on, for life doesn't end with death. Since this faith is presented in component (j) as knowledge, life after death is assumed here as a fact, and this gives this explication its eschatological dimension.

The full explication of the whole passage (Matt. 7:4-27) reads as follows:

The Two Builders

(a) I say all these things because I want people to know that they can live with God

(b) if you hear my words you can think: "if I live like this I can live with God"

(c) it will be good for you if you think like this

(d) it will be good for you ifyou live like this because of this

(e) it will be very bad for you if you don't live like this

(f) if you live like this you can always live with God

(g) you know that some very bad things can happen to you at some time

(h) if you don't live with God you can think then: "I can't live now"

(i) if you live with God you will not think like this

(j) you will know that you can always live if you live with God

This explication is consistent with the use of the image of rock in the Psalms, where God is the rock on which a person can build his or her life. For example:

The Lord is my rock and my fortress and my deliverance (Psalm 18:2)

For you are my rock and my fortress (Psalm 31:3)

And the Lord has been my defense

And my God the rock of my refuge. (Psalm 94:22) 
The references to "deliverance", "defense", and "refuge" link the image of God as one's ,rock" with the idea of "bad things happening to people". This is spelled out quite explicitly in Psalm 27:

For in the time of trouble

He shall hide me in his pavilion (...)

He shall set me high upon a rock. (Psalm 27:5)

Although the parable of Two Builders has often been compared with later Rabbinic literature, and especially with two parables attributed to Elisha ben Avuyah (dating from the second century), in fact its closest parallels are in such Old Testament images of God as a rock. First, it seems to make a lot of sense to link the images of floods and winds in Jesus' parable with the references to "the time of trouble" in the Psalms, rather than with any symbolic storms and torrents "in the catastrophe of the last judgment" (Luz 1989:452). And second, it makes a lot of sense to link Jesus' image of building a house on the rock with the references in the Psalms to God as the ultimate rock. On this interpretation, it is not human deeds which are presented as a reliable ground to build on, but "living with God"; and "living with God" is defined in the parable of Two Builders as trying to live according to the Sermon on the Mount. The great emphasis on "deeds" and on "obedience" which one finds in many commentaries obscures the fact that the Sermon on the Mount is about inner attitudes rather than about behaviour; and about behaviour only as expression of these attitudes. E.g. loving one's enemies or not judging other people cannot be a matter of "obedience". I think that the expression "to live like this" captures the message of the parable much better than the references to "doing". At the same time, the expression "to live like this" helps to reflect the link between Jesus' ethical teaching and his teaching about the Kingdom of God, which can be represented as "living with God".

From the point of view of our present discussion of the metaphor of "rock" it is particularly interesting to note what the important Rabbinic commentary on the Old Testament book of Deuteronomy, known as "Sifre on Deuteronomy" (1986), says about the passage from Deuteronomy (32.4) which calls God "The Rock": "The Rock, his work is perfect; for all his ways are justice. A God of faithfulness and without iniquity, just and right is he." "Sifre on Deuteronomy" links this passage with the ideas of God's reward for a "mitsvah" (that is, a right deed). Commenting on the phrase "A God of faithfulness" it says: „Just as he pays the completely righteous the reward of a mitsvah which is fulfilled in this world [after he is] in the world to come, so he pays the completely wicked the reward of a minor commandment which he fulfilled [while he is] in this world." And on the phrase "And without iniquity" Sifre comments: "When a man departs from the world, all his deeds come before him one by one and say to him: 'Thus 
and so you did on such a day and thus and so you did on another day. Do you declare these things to be accurate?' And he says 'Yes'. They say to him, 'Place your seal' and it is said: 'By the hand of every man he will seal, so that every man may know his work' (Job. 3.7)".

E. P. Sanders (1977:128) in his discussion of this passage stresses that "The theme of reward and punishment in the world to come is not a statement of justification by works, but an extension of the theory of the justice of God." While accepting Sanders' point, it is nonetheless interesting to note that the image of God as a rock is linked here with the notion of reward for a right deed: God is a rock who can be counted upon to reward the right deeds. Even though a person is saved by God's mercy and by the covenant between God and Israel and not by his or her own deeds, the notion of a right deed plays an important role here and it is linked with the image of a rock ${ }^{1}$.

${ }^{1}$ The metaphor of building on rock has of course a second use in the Gospels, in the famous words addressed by the Matthean Jesus (Matt. 16:18): “ and I (...) say to you that you are Peter, and on this rock I will build my church, and the gates of Hades shall not prevail against it". The question of whether or not these words originated with Jesus is disputed. Funk and Hoover (1993:207) seem to have no doubt that it is "a construction of Matthew". They write: "The play on Peter's name (petra in Greek means "rock") makes him the foundation on which the congregation is built: this undoubtedly reflects Peter's position in Matthew's branch of the emerging Christian movement. (...) All of this is Christian language and reflects conditions of the budding institution." It is interesting to note, however, that what Funk and Hoover call "Christian language" has in fact a close parallel in Rabbinic literature (Schechter 1961:59; Lachs 1987:256):

The matter is to be compared to a king who was desiring to build; but when he was digging for the purpose of laying the foundations, he found only swamp and mire. At last he hit on a rock, when he said: 'Here will I build.' So, too, when God was about to create the world, he foresaw the sinful generation of Enoch (...) and the wicked generations of the deluge (...) and he said, 'How shall I create the world whilst these generations are certain to provoke me (by their crimes and sins)? 'But when he perceived that Abraham would one day arise, he said 'Behold, I have found the petra on which to build and base the world.' Therefore he called Abraham Rock, as it is said, look to the rock from which you were hewn... [Isa. 51.1-2]

All commentators agree that Jesus' words addressed to Simon Peter in Matt. 16:18 point to an Aramaic original, (cf. e.g. Montefiore 1968[1937]:234, Albright and Mann 1971:195, Meier 1980:181). In particular, Meier highlights the fact that "up to this time in ancient Palestine, "Peter" (Petros in Greek, Kepha in Aramaic) had not been used as anyone's personal name. (...) Jesus is not changing one first name to another; he is conferring on Simon the new title, "the Rock". Meier suggests that in conferring this title on Simon, Jesus was referring to the passage in Isaiah (Isa. 51; 1-2) where Abraham is called "the rock" (from which the people of Israel were hewn), and that "similarly, Peter will be the human patriarch and foundation-stone of the new people of God."

Another interesting ramification of the "rock" motif is the polemical exchange between John the Baptist and the Pharisees (Matt. 3:7-10), where John warns the Pharisees and the Sadducees "not to rely on the principle of zekhut avot. "the merit of the fathers", that is to say, not to assume that they will escape punishment "by virtue of the fact that they are the descendants of the patriarch Abraham" (Lachs 1987:42). When John says "God is able from these stones to raise children to 
Jeremias (1971:116) emphasizes the fact that "Jesus said again and again that salvation was for sinners, not for the righteous" and that this message was without parallel at the time. („It is unique. The literature of Qumran has confirmed this uniqueness" ( 1971:12)). In view of this key feature of Jesus' teaching it is important to emphasize that his "house built on a rock" does not stand for the practice of righteousness (that is, for "right deeds"). Rather, it stands for the possibility of living with God open to all sinners (that is to people who think of themselves as "unworthy" rather than "worthy").

In summary, then, there are three key semantic ideas which I think provide the keys to the interpretation of the parable of Two Builders: first, the idea that a person can "live like this" (referring to the model of life developed in the "Sermon on the Mount"); second, the idea that very bad things can happen to people; and third, the idea that a person can always "live with God".

More generally speaking, I hope to have shown that here as elsewhere, the Natural Semantic Metalanguage based on universal human concepts is a useful hermeneutical tool, that is, an aid to understanding. Since this tool relies on universals and can be fashioned in any language, it can be used for explaining meanings not only within one language, but unrestrictedly across languages and cultures.

\section{References}

Albright, W. F. and C. S. Mann 1971. The Anchor Bible. Matthew: Introduction, translation and notes. New York: Doubleday.

Barclay, W. 1993[1975j. The Gospel of Matthew. Vol. 1. Edinburgh: The Saint Andrew Press. Bauman, C. 1985. The Sermon on the Mount: The modern quest for its meaning. Macon, Ga. Mercer University Press,

Betz, H. D. 1995. The Sermon on the Mount: A Commentary on the Sermon on the Mount, including the Sermon on the Plain (Matthew 5:3-7:27 and Luke 6:20-49). (Edited by Adela Yarbro.) Minneapolis: Fortress Press.

Bonhoeffer, D. 1959[1937]. The Cost of Discipleship. (Trans. R. H. Fuller.) London: SCM Press.

Braun, H. 1969. Spaetjuedisch-haeretischer und fruehchristlicher Radikalismus: Jesus von Nazareth und die essenische Qumransekte. 2 vol. Tuebingen: Mohr [Siebeck],

Brown, R. 1966. The Gospel according to John (Romans 1-12). Garden City: Doubleday.

Abraham" he seems to be invoking Isaiah's reference to Abraham as a rock from which the people of Israel will be hewn and contrasting the image of a "rock" (=Abraham) from which the people of Israel were hewn with that of any "stones" anywhere from which God can raise up true (spiritual) children to Abraham. 
Bultmann, R. 1958[1926], Jesus and the Word. (Trans. L.P. Smith and E. H. Lantero.) London: Collins.

Clement of Alexandria. Stromata. In: Alexander Roberts and James Donaldson (eds.). 1962.

The Ante-nicene Fathers: The Writings of the Fathers down to A.D. 325. (Vol II) Grand Rapids, Michigan: W.B.Eerdmans.

Funk, R, R. Hoover, and the Jesus Seminar. 1993. The Five Gospels: What did Jesus really say? New York: Macmillan.

Goddard, C. 1998. Semantic Analysis: A Practical Introduction. Oxford: Oxford University Press.

Hunter, A. M. 1953. Design for Life. London.

Jeremias, J. 1966. Rediscovering the Parables. London: SCM Press.

Jeremias, J. 1971. New Testament Theology. (Trans. J. Bowden.) London: SCM Press. Lachs, S. T. 1987. A Rabbinic Commentary. Hoboken, N.J.: KTAV Publishing House. Lakoff, G. and M. Johnson. 1980. Metaphors We Live By. Chicago : The University Of Chicago Press.

Limbeck, M, A. Bausch, G. Hegele, P. Neumann and W. Schopping. 1987. Die bessere

Gerechtigheit: Matthausevangelium. Stuttgart: Katolisches Biblewerk.

Limbeck, M. 1995. Matthaeus-Evangelium. Stuttgart: Katolisches Bibelwerk.

Luz, U. 1989. Matthew 1-7. Minneapolis: Fortress Press.

Meier, J. P. 1980. Matthew. Dublin: Veritas Press.

Montefiore. C. G. 1968 [1937]. The Synoptic Gospels. New York: KTAV Publishing

House. Oxford English Dictionary. 2nd Edition. CD ROM 1992.

Porpora, D. 2001. Landscapes of the Soul: The loss of moral meaningin America life.

New York: Oxford University Press.

Riesenfeld, H. 1952. Die Perikope von der Ehebrecherin in der friihkirchlichen Tradition.

Svensk Exegetisk Arsbok 17. pp 106-111.

Sanders, E. P. 1977. Paul and Palestinian Judaism: Aion. London: SCM Press. Schechter, S. 1961. Aspects of Rabbinic Theology. New York: Schocken.

Sifre. 1986. A Tannaitic Commentary on the Book of Deuteronomy. (Trans. Reuven

Hammer). New Haven: Yale University Press.

Strecker, G. 1988. The Sermon on the Mount. Nashville: Abingdon.

Tolstoy, L. 1958[1884], What I believe. In: Leo Tolstoy, A Confession. The Gospel ir.

Brief, and What I Believe. (Trans. Aylmer Maude.) London: Oxford University Press. Weil, S. 1951. Waiting on God. (Trans. E. Craufurd.) London: Routledge and Kegar. Paul.

Wierzbicka. A. 1996. Semantics: Primes and Universals. Oxford: Oxford Universitv Press 